\title{
IZAZOVI POPUNE VOJSKE SRBIJE AKTIVNOM I PASIVNOM REZERVOM
}

\author{
Slađan O. Veljković \\ Univerzitet odbrane u Beogradu, Vojna akademija \\ Miroslav M. Ostojić, Vinko P. Žnidaršič \\ Univerzitet odbrane u Beogradu, Škola nacionalne odbrane
}

Drelaskom na potpuno profesionalnu vojsku, Republika Srbija dobila je brojno manju, ali tehnički bolje opremljenu, efikasniju, savremeno organizovanu, osposobljenu za izvršenje misija i zadataka i finansijski održivu oružanu silu.

Opremanje Vojske Srbije modernim naoružanjem i vojnom opremom i uvođenje savremenih taktika, tehnika i procedura, podiže i povećava broj zahteva za obučenošću svih pripadnika vojske, što znači i pripadnika rezervnog sastava.

U tekstu se razmatra deo organizacije Vojske Srbije koji se odnosi na popunu aktivnom i pasivnom rezervom, aktuelna zakonsko-doktrinarna rešenja tih oblasti, pravi komparacija sa sličnim rešenjima u državama u okruženju i na kraju se kao rezultat identifikuju mogući izazovi i predlažu načini njihovog rešenja.

Ključne reči: popuna vojske; aktivna rezerva; pasivna rezerva; rezervni sastav; ratni raspored; stepen razvijenosti

\section{Uvod}

zmenjena priroda izazova, rizika i pretnji bezbednosti zahteva sveobuhvatan pristup u

odbrani nacionalnih interesa. Oni se štite, kako kroz saradnju subjekata bezbednosti unutar država, tako i uspostavljanjem partnerstva sa drugim državama i savezima, kroz kolektivnu bezbednost i odbranu. Kompleksnost pretnji bezbednosti društvu i državi koja se manifestuje kroz izmenjene unutrašnje i spoljne okolnosti u okruženju, novu fizionomiju savremenih sukoba, tehničko-tehnološki razvoj naoružanja i vojne opreme, finansijske izdatke za održavanje vojne sile, uticala je da sve veći broj razvijenih i srednje razvijenih zemalja, kod popune mirnodopske vojske prelazi sa opšte vojne obaveze na sistem profesionalne vojske.

Organizacija Vojske Srbije se razvija na najboljim domaćim i stranim iskustvima i dostignućima naučne misli u oblasti odbrane i vojne delatnosti. Organizacija Vojske Srbije je uslovljena: vrstama i karakterom izazova, rizika i pretnji bezbednosti; odbrambenim interesima Republike Srbije; potrebnim operativnim sposobnostima Vojske Srbije za realizaciju dodeljenih misija i zadataka; raspoloživim resursima odbrane i stepenom integrisanosti zemlje u međunarodne bezbednosne procese. ${ }^{1}$

\footnotetext{
${ }^{1}$ Doktrina Vojske Srbije, Medija centar odbrana, Beograd, strana 29.
} 
Doktrina Vojske Srbije iz 2010. godine je propisala načela organizovanja Vojske Srbije od kojih jedno podrazumeva da se Vojska Srbije popunjava profesionalnim pripadnicima, aktivnom i pasivnom rezervom. Predmet teksta su delatnosti i procesi u komandovanju i problemi sa kojima mogu da se suoče komande svih nivoa u popuni aktivnom i pasivnom rezervom.

U savremenom bezbednosnom okruženju, sa smanjenjem i profesionalizacijom Vojske Srbije planiranje, organizovanje i funkcionisanje rezervnog sastava mora zadovoljiti zahteve po meri potreba savremeno organizovane vojske i društva za odbranu zemlje. Zahtevi, koje rezervni sastav treba da ispuni, nalaze se u strukturnim ${ }^{2}$ i funkcionalnim ${ }^{3}$ svojstvima Vojske Srbije i drugih snaga odbrane ${ }^{4}$ u novonastalim uslovima u okruženju, koji proizilaze iz stanja u državi, novih međunarodnih odnosa i položaja naše zemlje u njima. Komparativnom analizom oružanih snaga u okruženju, kao i analizom aktuelnih zahteva i potreba Vojske Srbije i drugih snaga odbrane usvojen je konceptualni model aktivne i pasivne rezerve u sistemu vojne obaveze, koji treba da obezbedi sigurnu i efikasnu mirnodopsku i ratnu popunu Vojske Srbije i popunu drugih snaga odbrane.

Opšti cilj uvođenja aktivne i pasivne rezerve jeste obezbeđivanje dodatnih ljudskih resursa, koji će omogućiti pouzdanu i efikasnu popunu komandi, jedinica i ustanova Vojske Srbije i Ministarstva odbrane odabranim, motivisanim i obučenim kadrom, posebno specijalnostima od posebnog značaja i nedostajućim specijalnostima.

U skladu sa opisanim ciljem uvođenja aktivne i pasivne rezerve, kao novog načina organizacije rezervnog sastava Vojske Srbije nameću se dva pitanja: (1) Koje je mesto i uloga aktivne i pasivne rezerve u izvršavanju misija i zadataka Vojske Srbije i (2) Koje namenske snage Vojske Srbije možemo popunjavati aktivnom i pasivnom rezervom?

Odgovorom na ta pitanja sveobuhvatno se sagledavaju misije i zadaci Vojske Srbije u kojima se može angažovati aktivna i pasivna rezerva i definišu se namenske snage koje bi trebalo popuniti ovakvim načinom.

Način popune je problem koji se može negativno odraziti na izvršavanje zadataka iz svakodnevnog života i rada komandi, jedinica i ustanova VS, a nedostatak pojedinih (kritičnih) specijalnosti, umanjuje operativne i funkcionalne sposobnosti.

\section{Rezervni sastav u Republici Srbiji}

Radi potpunijeg razumevanja popune Vojske Srbije kao i izazova s kojima se ona može suočiti, potrebno je sagledati strukturu sistema nacionalne bezbednosti Republike Srbije, kao celine elemenata čijom delatnošću se ostvaruje zaštita nacionalnih interesa Republike Srbije.

Sistem nacionalne bezbednosti u širem smislu čine najviši organi zakonodavne, izvršne i sudske vlasti: Narodna skupština i predsednik Republike Srbije, Savet za nacionalnu bezbednost, Vlada, sudovi i tužilaštva. U užem smislu, sistem nacionalne bezbednosti

\footnotetext{
${ }^{2}$ Vojska Srbije se strukturno deli na vidove, rodove i službe (Doktrina Vojske Srbije, strana 17).

${ }^{3}$ Vojska Srbije se funkcionalno organizuje u komande, jedinice i ustanove na strategijskom, operativnom i taktičkom nivou. Komande, jedinice i ustanove vidova, rodova i službi organizuju se u snage za reagovanje, glavne odbrambene snage i snage ojačanja (Doktrina Vojske Srbije, strana 17).

${ }^{4}$ Pod pojmom druge snage odbrane podrazumevaju se organizovane strukture subjekata sistema odbrane (državni organi, organi državne uprave, organi autonomnih pokrajina, jedinice lokalne samouprave, privredna društva, druga pravna lica i preduzetnici od značaja za odbranu).
} 
čine: sistem odbrane, snage Ministarstva unutrašniih poslova, bezbednosno-obaveštajni sistem i privremeno formirani organi i koordinaciona tela za pojedine krize. ${ }^{5}$

Sistem odbrane predstavlja jedinstvenu, strukturno uređenu i funkcionalnu celinu snaga i subjekata odbrane čiji je cilj zaštita odbrambenih interesa Republike Srbije. Zaštita odbrambenih interesa se realizuje kroz vojnu i civilnu odbranu. Nosilac vojne odbrane je Vojska Srbije, a civilne odbrane su: državni organi, organi državne uprave, organi autonomnih pokraiina, organi jedinica lokalne samouprave, privredna društva, javne službe i ostali subjekti i snage sistema odbrane. ${ }^{6}$

Subjekti sistema odbrane su: građani, državni organi, privredna društva, druga pravna lica, preduzetnici i Voiska Srbiie. Snage odbrane čine liudski i materijalni_potencijali Republike Srbije, odnosno organizovane strukture subjekata sistema odbrane. ${ }^{7}$

\section{Pojmovno određenje rezerve}

U literaturi ne postoji opšteprihvaćena definicija „rezerve“, kao osnovnog kategorijalnog pojma. Tumačenje je različito i zbog toga se javljaju poteškoće, ali je vidljiva sličnost i suštinska određenost tog pojma sa vojnog aspekta.

Po leksikonu stranih reči i izraza od Milana Vujaklije, pojam rezerva, potiče od francuske reči „reserve“ što u opštem prevodu znači „zadržano pravo, ograda, zaliha, pričuva, ono što je ostavljeno ili što se čuva za slučaj potrebe“. U vojnom smislu značenje rezerve jeste da su to vojnici koji su odslužili vojni rok, stalni sastav vojske koji se poziva „pod zastavu" samo u slučaju rata. Takođe, u odnosu na mesto u borbenom rasporedu u toku izvođenja borbenih dejstava, pod rezervom se podrazumeva vojska koja nije u prvom borbenom redu, nego na raspolaganju vrhovnom (strategijska rezerva) ili nekom drugom komandantu da je upotrebi tamo gde se ukaže potreba, to je „dopunska vojska, dopuna“. ${ }^{\circ}$

Po rečniku srpskog jezika, rezerva je reč latinskog porekla i ima više značenja, zavisno od oblasti primene: opšte značenje, u vojnom smislu, u sportu, u gramatici i jeziku. U vojnom smislu rezerva znači: „a) status koji imaju vojni obveznici koji su služili vojni rok ili im je prestala aktivna vojna služba i pozivaju se na vojne vežbe po potrebi i b) deo vojske koji se u borbi angažuje po potrebi“. ${ }^{9}$

$U$ vojnoj enciklopediji, navedeno je da rezerva potiče od latinske reči „reserve“ što znači uštedeti, a vojna rezerva znači „živa sila i materijalna sredstva predviđeni za popunu i snabdevanje oružanih snaga u ratu (na kopnu, moru i u vazduhu) ili manevarske snage sa kojima komandant (zavisno od nivoa komandovanja) manevrom utiče na tok borbe radi postizanja odlučnog uspeha,...". 10

Po vojnom leksikonu, slično kao u Leksikonu stranih reči i izraza od Milana Vujaklije, rezerva je reč francuskog porekla i znači elemenat borbenog poretka taktičkih, združeno-

\footnotetext{
${ }^{5}$ Strategija nacionalne bezbednosti Republike Srbije ("Službeni glasnik RS" broj 88/09), strana 29.

${ }^{6}$ Strategija odbrane Republike Srbije ("Službeni glasnik RS" broj 88/09), strana 14.

${ }^{7}$ Isto.

${ }^{8}$ Milan Vujaklija, Leksikon stranih reči i izraza, Beograd, Prosveta, 1980, strana 787.

${ }^{9}$ Rečnik srpskog jezika, Novi Sad, Matica Srpska, 2007, strana 1152.

${ }^{10}$ Vojna enciklopedija, Beograd, Redakcija vojne enciklopedije, 1996, tom 8, strana 275.
} 
taktičkih jedinica, operativnih sastava i strategijsko-operativnih grupacija. U definisanju pojma vojne rezerve, daje se detaljnije određenje pojma, to su „ljudstvo i materijalna sredstva koji čine jednu od osnova ratnog potencijala zemlje ili koalicije zemalja, potrebnu oružanim snagama za život, rad i oružanu borbu. Predstavljaju posebnu kategoriju, pa se nazivaju i državne ratne (vojne) rezerve ili rezerva narodne odbrane, za razliku od robnih rezervi kojima se koristi ekonomika zemlje za vođenje rata....".

Posmatrajući zajedničke osobine navedenih određenja, možemo reći da „rezerva" u vojnom smislu podrazumeva, s jedne strane vojne jedinice ili sastave koje komandant predviđa za angažovanje po ukazanoj potrebi tokom borbenih dejstava, i s druge strane ljudski i materijalni potencijal države namenjen za popunu ratnih jedinica. Među navedenim određenjima nema razlike u tumačenju značenja suštine pojma, razlika se pojavljuje u izboru reči koji objašnjavaju pojam.

\section{Organizacija rezervnog sastava u Republici Srbiji}

Vojna obaveza je pravo i dužnost građana da se pripremaju i osposobljavaju za učešće u odbrani i zaštiti suverenosti, nezavisnosti, teritorijalne celovitosti i bezbednosti Republike Srbije. Vojnu obavezu u miru, vanrednom ili ratnom stanju imaju svi građani koji se pripremaju i osposobljavaju za izvršenje vojnih dužnosti i drugih zadataka odbrane u skladu sa zakonom. ${ }^{12}$

Sistem vojne obaveze može se posmatrati kao skup međusobno povezanih elemenata koji sačinjavaju funkcionalnu celinu u smislu realizacije mirnodopske i ratne popune Vojske Srbije i drugih snaga odbrane. On se u smislu osnovne namene, može podeliti na podsisteme: 1) regrutna obaveza, 2) dobrovoljno služenje vojnog roka i 3) obaveze u rezervnom sastavu.

Rezervni sastav obuhvata celokupan raspoloživi potencijal lica državljana Republike Srbije koja su regulisala obavezu služenja vojnog roka ili su tu obavezu regulisala na drugi način, a koji su sposobni za službu u rezervnom sastavu. Obavezi služenja u rezervnom sastavu podležu i građani - vojni obveznici koji nisu bili u obavezi i nisu služili vojni rok u skladu sa odlukom Narodne skupštine o obustavi služenja vojnog roka, kao i žene koje su dobrovoljno služile vojni rok, žene profesionalna vojna lica kojima je prestala profesionalna vojna služba i žene koje su uvedene u vojnu evidenciju.

Svi oni se mogu rasporediti u ratne komande, jedinice i ustanove Vojske Srbije i Ministarstva odbrane, u sastave civilne zaštite, u sastav drugih snaga odbrane ili mogu ostati neraspoređeni. Vojni obveznici koji su odslužili vojni rok sa oružjem prevashodno se raspoređuju u rezervni sastav Vojske Srbije, a prema potrebi u druge snage odbrane, osim lica koja imaju raspored u Ministarstvu unutrašnjih poslova. ${ }^{13}$ Vojni obveznici koji nisu služili vojni rok raspoređuju se u načelu u sastave civilne zaštite, ali se mogu raspoređivati i u sve ostale subjekte sistema odbrane, izuzev Vojske Srbije, zavisno od potreba, znanja i sposobnosti za izvršenje poslova i zadataka.

\footnotetext{
${ }^{11}$ Vojni leksikon, Beograd, VIZ, 1981, strana 530.

${ }^{12}$ Zakon o vojnoj, radnoj i materijalnoj obavezi ("Službeni glasnik RS" broj 88/09), član 2.

${ }^{13}$ Isto, član 50.
} 
Rezervni sastav Republike Srbije obuhvata: ${ }^{14}$

1) rezervni sastav Vojske Srbije,

2) rezervni sastav civilne zaštite i drugih snaga odbrane i

3) neraspoređene vojne obveznike.

Obavezi služenja u rezervnom sastavu podležu vojni obveznici ${ }^{15}$ :

1) koji su odslužili vojni rok,

2) koji su regulisali obavezu služenja vojnog roka na drugi način (ako su ocenjeni sposobnim za vojnu službu) i

3) žene vojni obveznici koje se vode u evidenciji.

Obaveza lica u rezervnom sastavu nastaju od dana otpuštanja sa služenja vojnog roka ili civilne službe, od dana kada je obaveza služenja vojnog roka i civilne službe regulisana na drugi način, odnosno od dana prestanka profesionalne vojne službe i traje do kraja kalendarske godine u kojoj vojni obveznik (muškarac) navršava 60 godina života i vojni obveznik (žena) navršava 50 godina života. ${ }^{16}$

Zakonom o VS propisano je da se Vojska Srbije sastoji od stalnog i rezervnog sastava. Stalni sastav čine profesionalni pripadnici i vojnici na služenju vojnog roka. Rezervni sastav Vojske Srbije čine rezervni oficiri, rezervni podoficiri i vojnici u rezervi. Rezervni sastav Vojske Srbije se deli na aktivnu i pasivnu rezervu. ${ }^{17}$

Aktivna rezerva predstavlja „obučeni rezervni sastav Vojske Srbije koji se angažuje za popunu jedinica Vojske Srbije i Ministarstva odbrane, radi izvršavanja zadataka u određenom vremenskom periodu i čija su prava i dužnosti regulisana zakonom i zaključenim ugovorom“. ${ }^{18}$.

Pripadnici aktivne rezerve se angažuju na zadacima održavanja operativne i funkcionalne sposobnosti, obučavanja, angažovanja u misijama i na drugim zadacima u skladu sa zaključenim ugovorom. Planskim i intenzivnijim obučavanjem i kondicioniranjem pripadnika aktivne rezerve obezbeđuje se viši stepen osposobljenosti u odnosu na lica iz pasivne rezerve, radi popune komandi, jedinica i ustanova Vojske Srbije kojima je određen viši stepen operativne i funkcionalne sposobnosti. ${ }^{19}$

Aktivnu rezervu čine vojni obveznici koji ispunjavaju „opšte uslove za službu u aktivnoj rezervi“ ${ }^{\text {“20 }}$ i dobrovoljno su zaključili ugovor sa Ministarstvom odbrane o angažovanju u jedinicama Vojske Srbije i Ministarstva odbrane. Najbitniji uslov za službu u aktivnoj rezervi je osposobljenost za dužnosti u Vojsci Srbije.

Zakonska i podzakonska dokumenta, za razliku od aktivne, nisu dala preciznu definiciju pasivne rezerve. Regulativa je dala samo ko sačinjava pasivnu rezervu i kaže da je „čine pripadnici rezervnog sastava, koji imaju ratni raspored u komandama, jedinicama i ustanovama Vojske Srbije, Ministarstvu odbrane, državnim organima, civilnoj zaštiti i drugim snagama odbrane".

\footnotetext{
${ }^{14}$ Zakon o vojnoj, radnoj i materijalnoj obavezi ("Službeni glasnik RS" broj 88/09 ), član 48.

${ }^{15}$ Isto.

${ }^{16}$ Isto, član 49.

${ }^{17}$ Zakon o Vojsci Srbije ("Službeni glasnik RS" broj 116/07 , 88/09 i 10/15), član 5.

${ }^{18}$ Zakon o vojnoj, radnoj i materijalnoj obavezi ("Službeni glasnik RS" broj 88/09), član 54.

${ }^{19}$ Zakon o vojnoj, radnoj i materijalnoj obavezi ("Službeni glasnik RS" broj 88/09), član 54.

${ }^{20}$ Uredba o službi u aktivnoj rezervi ("Službeni glasnik RS" broj 47/11), član 2.

${ }^{21}$ Zakon o vojnoj, radnoj i materijalnoj obavezi ("Službeni glasnik RS" broj 88/09), član 54.
} 
Doktrina Vojske Srbije takođe ističe ko čini pasivnu rezervu: vojnici, podoficiri i oficiri u rezervi koji popunjavaju ratne jedinice Vojske Srbije. ${ }^{22}$

Polazeći od zakonskih i doktrinarnih određenja može se zaključiti da je pasivna rezerva, deo rezervnog sastava VS, koji se angažuje po potrebi i planu, za popunu komandi, jedinica i ustanova Vojske Srbije i Ministarstva odbrane, državnih organa, civilne zaštite i drugih snaga odbrane, radi izvršavanja dodeljenih misija i zadataka.

\section{Komparacija sa rezervnim sastavom oružanih snaga država u okruženju}

Prelazak na sistem profesionalizacije u mirnodopskoj popuni vojske zemalja u okruženju podrazumevao je radikalno smanjenje oružanih snaga i uvođenje znatno viših standarda operativnih i funkcionalnih sposobnosti komandi, jedinica i ustanova, kao i definisanje novog koncepta popune rezervnim sastavom.

Većina zemalja opredelila se da, pored opšte (pasivne) rezerve koja je namenjena za odbranu zemlje od agresije spolja, razvije i ugovornu (aktivnu) rezervu. Potreba uspostavljanja ugovorne, odnosno aktivne rezerve ima svoje uporište u obezbeđenju malobrojne i vrhunski osposobljene rezerve, koja će pouzdano i kompetentno popuniti određena formacijska mesta jedinica u miru.

U evropskim državama postoje različita rešenja organizovanja, kako samih oružanih snaga, tako i rezervnog sastava. Razlika se kreće od nepostojanja obavezne rezerve već samo ugovorne rezerve (Francuska), postojanja samo opšte obavezne rezerve (Rumunija), do postojanja i aktivne (ugovorne) i pasivne (obavezne) rezerve (Slovenija, Hrvatska, Bugarska, BJR Makedonija, Mađarska, Nemačka).

Rezervni sastav oružanih snaga Hrvatske čini: aktivnu (ugovornu) i pasivnu rezervu. Aktivna rezerva se popunjava od vojnika koji su odslužili vojni rok na dobrovoljnoj osnovi. Namenjena je za popunu, kako jezgara ratnih jedinica, tako i ratnih jedinica za učešće u operacijama odgovora na krize u zemlji i inostranstvu.

Rezervni sastav vojske Slovenije čini: ugovornu (aktivnu) i mobilizacijsku (pasivnu) rezervu. Ugovornu ili aktivnu rezervu, čine vojni obveznici koji imaju raspored u mirnodopskim jedinicama vojske i dobrovoljno sklopljen ugovor sa Ministarstvom odbrane, na određeni period. U rezervu se pozivaju za potrebe odbrane države, na vežbe ili izvršavanja drugih zadataka. Dok traje ugovor, pripadnici aktivne rezerve mogu biti pozvani da učestvuju u multinacionalnim operacijama i za pomoć u prirodnim i drugim nesrećama. Mobilizacijskom ili pasivnom rezervom vrši se popuna ratnih jedinica vojske.

Rezervni sastav oružanih snaga Bugarske čini: stalnu (aktivnu) i mobilizacijsku (pasivnu) rezervu. Stalna rezerva namenjena je za popunu, do punog brojnog stanja, aktivnih jedinica u miru i upućivanje u multinacionalne operacije, a mobilizacijska rezerva za popunu ratnih jedinica OS, za vreme mobilizacije.

Rezervni sastav oružanih snaga Mađarske čine: dobrovoljna (aktivna) i obavezna (pasivna) rezerva. Dobrovoljnom rezervom vrši se dopuna profesionalnog sastava ili kao privremena zamena iz bilo kog razloga (vojna vežba, zadaci u odbrani od katastrofa, go-

\footnotetext{
${ }^{22}$ Doktrina Vojske Srbije, Beograd, 2010, strana 16.
} 
dišnji odmori članova stalnog sastava i sl.) i u multinacionalnim operacijama. Aktiviranje obavezne rezerve predviđeno je samo u slučaju neposredne ratne opasnosti i proglašenja ratnog stanja, što podrazumeva i angažovanje dobrovoljne rezerve.

Rumunija nema aktivnu rezervu već samo rezervu koju čine vojnici koji su odslužili vojni rok i bivši vojnici po ugovoru i profesionalna vojna lica, do navršenih 55 godina života. Lica iz rezerve nemaju nikakvih obaveza prema vojsci i obratno (ne pozivaju se na vežbe, obuku i sl.). Njihovo angažovanje je predviđeno u slučaju vanrednog ili ratnog stanja ili velikih elementarnih katastrofa.

Rezervni sastav oružanih snaga Francuske zasnovan je na dobrovoljnoj osnovi, a sastoji se iz: operativne rezerve i građanske rezerve (civilna zaštita). Operativna rezerva namenjena je za ojačavanje postojećih vojnih kapaciteta oružanih snaga. Čine je civilna lica i bivša profesionalna vojna lica angažovana ugovorom. Angažuje se za izvršavanje misija i zadataka Vojske u zemlji i u multinacionalnim operacijama.

Rezerva oružanih snaga Nemačke organizovana je u: rezervu za ojačanje, kadrovsku rezervu i opštu kadrovsku rezervu. Rezerva za ojačanje i kadrovska rezerva čine aktivnu rezervu i namenjena je za popunu formacijskih mesta u okviru aktivnih jedinica vidova oružanih snaga i ministarstva odbrane kao i za popunu delimično aktivnih jedinica i jezgra jedinica. Pasivnu rezervu čini opšta kadrovska rezerva i ona popunjava ratne jedinice.

Komparativnom analizom sa rešenjima država u okruženju, može se zaključiti da je uvođenje novog koncepta popune rezervnog sastava u VS izvršeno na bazi njihovih iskustava, uz uvažavanje sopstvenih mogućnosti i potreba. Sa nekim bivšim državama SFRJ (Republikom Hrvatskom, BJR Makedonijom i Republikom Slovenijom) imamo slična rešenja u načinu popune vojske rezervnim sastavom (aktivna i pasivna rezerva), u pružanju pogodnosti pripadniku aktivne rezerve kada vrši službu u vojsci (izjednačeni sa profesionalnim sastavom za vreme vršenja dužnosti u vojsci), i u mirovanju prava i obaveza iz radnog odnosa kod poslodavca za vreme angažovanja u misijama i na zadacima vojske. Pristup pružanja pogodnosti pripadniku aktivne rezerve kada ne vrši službu u vojsci nam je različit (u Hrvatskoj prilikom zaključenja ugovora prima $60 \%$ prosečne zarade, u Sloveniji ima pogodnost oslobađanja od poreza na primljene novčane prinadležnosti u vojsci i dobija jednokratni dodatak pri produženju ugovora, dok našeg rezervistu pripada novčana naknada, koju određuje ministar odbrane za svaki mesec trajanja ugovora). U svim navedenim državama predviđeno je da se pripadnici aktivne rezerve, po isteku ugovora, prevode u pasivnu rezervu.

U ekonomski razvijenim državama (Francuska, Nemačka ...) postoji razrađen sistem pružanja pogodnosti, radi animacije za pristupanje rezervnom sastavu, u toku i posle služenja u rezervnom sastavu, kao i pogodnostima koje se daju poslodavcima kod kojih su rezervisti zaposleni. Naravno, ove pogodnosti uslovljene su ekonomskim i finansijskim mogućnostima zemlje.

\section{Zadaci i angažovanje aktivne i pasivne rezerve u Vojsci Srbije}

Strategijskim pregledom odbrane Republike Srbije iz 2011. godine, definisano je da veličina mirnodopskog sastava Vojske Srbije bude u skladu sa potrebama i mogućnostima Republike Srbije i da se kreće oko 0,2-0,4\% populacije države. U skladu s tim, izvršena je i projekcija mirnodopske brojne veličine Vojske Srbije na oko 30.000 pripadnika (oko 28.000 profesionalnih pripadnika i 2.000 pripadnika aktivne rezerve). 
Uvažavajući izazove, rizike i pretnje bezbednosti Republici Srbiji, globalno i regionalno okruženje, demografske i materijalne potencijale Republike Srbije i operativne potrebe odbrane Republike Srbije, brojna veličina Vojske Srbije u ratu projektovana je na oko 85.000 pripadnika.

Iz navedenih podataka identifikuju se potrebe Vojske Srbije za rezervnim sastavom broja oko 57.000 pripadnika.

\section{Razlozi za uvođenje aktivne rezerve u Vojsci Srbije}

Uvođenje aktivne rezerve, kao načina popune operativnih jedinica Vojske Srbije je izazvano višestrukim razlozima, zasniva se na sistemskim zakonima i strategijsko-doktrinarnim dokumentima, od kojih ćemo neke najvažnije navesti:

- Vojska Srbije zbog racionalnosti ima jedinice različitih stepena gotovosti i razvijenosti, ${ }^{23}$ koji se kreću od R-0 do R-4. Manji broj jedinica imaju najviši stepen razvijenosti R-0, dok skoro $50 \%$ jedinica ima srednji stepen razvijenosti $\mathrm{R}-2$. Model aktivne rezerve nudi rešenje popune formacijskih mesta mirnodopskog sastava, radi podizanja nivoa gotovosti, angažovanjem obučenog i motivisanog ljudstva.

- Opremanje Vojske Srbije modernim sredstvima i uvođenje savremenih procedura podiže i usložava zahteve za obučenošću pripadnika rezervnog sastava. Pripadnici rezervnog sastava koji ulaze u sastav jedinica Vojske Srbije i Ministarstva odbrane treba da budu podvrgnuti intenzivnoj, kontinuiranoj i savremenoj obuci. Upravo aktivna rezerva svojom obučenošću, ovde nalazi svoje mesto.

- Odlukom Narodne skupštine o „zamrzavanju“ vojne obaveze, u značajnoj meri je smanjena kadrovska osnova za popunu vojnicima, onim građanima koji će dobrovoljno služiti vojni rok. Najčešći razlozi dobrovoljnog služenja vojnog roka su želje da se u VS obezbedi alternativna profesionalna karijera ili da po završenoj obuci jedan period svog radnog veka provedu u profesionalnoj vojnoj službi. Postojanje aktivne rezerve pruža institucionalne i profesionalne mogućnosti ovoj kategoriji građana.

- Iskustva evropskih zemalja ukazuju na činjenicu, da ugovorna (aktivna) rezerva predstavlja dobru kadrovsku osnovu za angažovanje u operacijama izgradnje i očuvanja globalnog i regionalnog mira i bezbednosti. U pojedinim skandinavskim zemljama odnos učešća ugovorne rezerve i stalnog profesionalnog sastava se u mirovnim operacijama kreće do 9:1 u korist ugovorne (aktivne) rezerve.

\section{Angažovanje aktivne i pasivne rezerve u misijama i zadacima Vojske Srbije}

Da bi odredili u kojim misijama i zadacima možemo angažovati aktivnu rezervu, moramo uporediti odredbe Zakona o Vojsci Srbije, Zakona o vojnoj, radnoj i materijalnoj obavezi, Zakona o upotrebi Vojske Srbije i drugih snaga odbrane u multinacionalnim operacijama van granica Republike Srbije, Doktrinu Vojske Srbije i Pravilnik za unutra-

\footnotetext{
${ }^{23}$ Stepen razvijenosti predstavlja kvantitavan odnos broja formacijskih mesta u miru u odnosu na broj formacijskih mesta u ratu po objedinjenoj formaciji, Pravilnik za unutrašnje uređenje i sistematizaciju formacijskih mesta u Vojsci Srbije, (SVL broj 27/09, 31/10 i 05/17), član 23.
} 
Sistem odbrane

šnje uređenje i sistematizaciju formacijskih mesta u Vojsci Srbije ${ }^{24}$ (u delu koji se odnosi na klasifikaciju jedinica po stepenu razvijenosti).

Upoređivanjem gore nabrojanih zakona, doktrine i pravilnika, može se zaključiti da aktivna rezerva treba da izvršava sledeće misije i zadatke VS:

1. U misiji odbrane Republike Srbije od oružanog ugrožavanja spolja, angažovanjem u izvršavanju zadataka: odvraćanja od oružanog ugrožavanja, odbrane teritorije i vazdušnog prostora,

2. U misiji učešća u izgradnji i očuvanju mira u regionu i svetu, angažovanjem u izvršavanju zadatka: učešća u multinacionalnim operacijama, 9 meseci i to 3 meseca za pripremu i 6 meseci za izvršenje misije,

3. U misiji podrške civilnim organima vlasti u suprotstavljanju pretnjama bezbednosti angažovanjem u izvršavanju zadataka: pomoći civilnim vlastima u suprotstavljanju unutrašnjem ugrožavanju bezbednosti, terorizmu, separatizmu i organizovanom kriminalu i pomoć civilnim vlastima u slučaju prirodnih nepogoda, tehničko-tehnoloških i drugih nesreća, do 6 meseci godišnje i

4. U obučavanju radi osposobljavanja za misiju odbrane od oružanog ugrožavanja, do 45 dana godišnje i pozivanja na vojnu vežbu do 90 dana.

U izvršavanju misija i zadataka Vojske Srbije, pripadnici aktivne rezerve se angažuju u jedinici sa kojom su zaključili ugovor i mogu izvršavati zadatke u okviru misije u trajanju do najviše 9 meseci i to "3 meseca za pripremu i 6 meseci za izvršenje misije“. ${ }^{25}$

Na osnovu Zakona o upotrebi Vojske Srbije i drugih snaga odbrane u multinacionalnim operacijama van granica Republike Srbije, pripadnici aktivne rezerve mogu biti upućeni u misije učešća u izgradnji i očuvanju mira u regionu i svetu, odnosno na zadacima u okviru multinacionalnih operacija. ${ }^{26}$

Imajući u vidu da je stalni i najvažniji zadatak Vojske Srbije u miru, obučavanje i osposobljavanje za izvršenje dodeljenih misija i zadataka, može se uočiti da će ovo biti i osnovni zadatak na kome će se u miru angažovati aktivna rezerva. Zakonom je regulisano da se pripadnici aktivne rezerve pozivaju u toku kalendarske godine na redovno obučavanje do 45 dana $^{27}$ i na vojnu vežbu najviše do 90 dana u toku jedne godine ${ }^{28}$. Ovaj period omogućava kvalitetnu obuku na složenim sredstvima i garantuje uspešnu realizaciju zadataka u jedinici.

Zakonska regulativa takođe nije precizno definisala misije i zadatke u kojima može biti angažovana i pasivna rezerva. Propisano je da se pripadnici pasivne rezerve angažuju „i za izvršavanje zadataka pružanja pomoći stanovništvu i spasavanju materijalnih dobara usled prirodnih katastrofa i drugih nesreća“" ${ }^{29}$

$\mathrm{Na}$ osnovu toga može se zaključiti da se pasivna rezerva može angažovati u izvršavanju sledećih misija i zadataka:

1. U misiji odbrane Republike Srbije od oružanog ugrožavanja spolja, angažovanjem u izvršavanju zadatka: odbrana teritorije i odbrana vazdušnog prostora,

\footnotetext{
${ }^{25}$ Zakon o vojnoj, radnoj i materijalnoj obavezi ("Službeni glasnik RS" broj 88/09), član 54.

${ }^{26}$ Zakon o upotrebi Vojske Srbije u multinacionalnim operacijama van granica Republike Srbije ("Službeni glasnik RS" broj 88/09), član 13.

${ }^{27}$ Zakon o vojnoj, radnoj i materijalnoj obavezi ("Službeni glasnik RS" broj 88/09), član 54

${ }^{28}$ Isto, član 51

${ }^{29}$ Isto.
} 
2. U misiji podrške civilnim organima vlasti u suprotstavljanju pretnjama bezbednosti angažovanjem u izvršavanju zadatka: pomoć civilnim vlastima u slučaju prirodnih nepogoda, tehničko-tehnoloških i drugih nesreća i

3. Obučavanje u toku godine, do 15 dana u toku kalendarske godine i na vojnu vežbu do 90 dana.

Lica u rezervnom sastavu Vojske Srbije u svojstvu pasivne rezerve navedene misije i zadatke će izvršavati u sastavu ratne jedinice u kojoj imaju ratni raspored.

Zakonska odredba, definisanjem da je pripadnik rezerve odslužio vojni rok i da mu se određuje ratni raspored u skladu sa njegovom osposobljenošću za konkretnu dužnost, definiše i angažovanje pasivne rezerve u zadacima koji proističu iz prve i treće misije Vojske Srbije.

To vreme mora biti dovoljno za kondiciranje i proširivanje stečenih znanja koja će biti iskorištena u realizaciji misija i zadataka jedinica u kojima su rezervisti raspoređeni.

\section{Popuna komandi, jedinica i ustanova Vojske Srbije aktivnom i pasivnom rezervom}

Doktrinarnim dokumentima u oblasti odbrane, Srbija se opredelila za „načela organizovanja VS“30 trokomponentnosti sastava i trokomponentnosti namene Vojske Srbije. Trokomponentnost sastava podrazumeva da se Vojske Srbije popunjava profesionalnim pripadnicima, aktivnom i pasivnom rezervom. ${ }^{31}$

\section{Izvori popune komandi, jedinica i ustanova aktivnom i pasivnom rezervom}

Analizirajući pojmovno određenje aktivne rezerve, zaključujemo kojom kategorijom vojnih obveznika je možemo popuniti, uz naravno poštovanje principa dobrovoljnosti:

- Raspoređenim licima iz rezervnog sastava (pripadnici pasivne rezerve), odnosno vojnim obveznicima kojima je određen ratni raspored u komandama, jedinicama i ustanovama Vojske Srbije i Ministarstva odbrane, sem licima koja su raspoređena u Policiji.

- Licima iz rezervnog sastava kojima je prestao radni odnos u svojstvu profesionalnog vojnog lica (oficir, podoficir, profesionalni vojnik), a po godinama života im nije istekla obaveza služenja u rezervnom sastavu i

- Neraspoređenim licima iz rezervnog sastava koji su odslužili vojni rok sa oružjem ili su završili kurs za rezervne oficire.

Popuna Vojske Srbije aktivnom rezervom vrši se na osnovu javnog konkursa, u skladu sa Planom popune kojim se za svaku kalendarsku godinu određuje broj i specijalnosti lica koja se mogu angažovati u aktivnoj rezervi. Konkurs raspisuje organizacijska jedinica Mini-

\footnotetext{
${ }^{30}$ Načela organizovanja Vojske Srbije su usvojeni stavovi o organizovanju i razvoju Vojske Srbije za realizaciju misija i zadataka.

${ }^{31}$ Doktrina Vojske Srbije, Beograd, 2010, strana 16.
} 
starstva odbrane nadležna za kadrove, na predlog Generalštaba Vojske Srbije. Opšte uslove za službu u aktivnoj rezervi propisuje Vlada, na predlog ministra odbrane. ${ }^{32}$ Od opštih uslova, najbitniji je onaj koji se tiče godina starosti lica koja se primaju u aktivnu rezervu. Članom 2. stav 4. Uredbe o službi u aktivnoj rezervi propisano je „da je prilikom stupanja u aktivnu rezervu mlađe od 50 godina (za oficira), odnosno 40 godina (za podoficira i vojnika), osim za profesionalnog pripadnika VS kome je prestala profesionalna vojna služba“.

Posebne uslove za prijem u aktivnu rezervu, u skladu sa potrebama popune i specifičnostima formacijskih mesta na koje se predviđa angažovanje aktivnog rezerviste, određuje Ministarstvo odbrane na predlog Generalštaba Vojske Srbije. ${ }^{33}$

Posebni uslovi se preciziraju prilikom raspisivanja konkursa. Njima se bliže određuju kriterijumi u pogledu stručnosti i sposobnosti potrebnih za angažovanje na formacijskom mestu za koje se zaključuje ugovor, a koji se tiču vojno-stručne osposobljenosti, stepena stručne spreme, specijalnosti, usavršavanja, medicinsko-psihološke i fizičke sposobnosti i bezbednosnih uslova.

Broj i strukturu lica (po činu, rodu, službi, specijalnosti i jedinicama) sa kojima se može zaključiti ugovor o angažovanju u aktivnoj rezervi, na predlog načelnika Generalštaba Vojske Srbije, odobrava ministar odbrane u skladu sa planom i odobrenim novčanim sredstvima za tu namenu.

Vojni obveznik primljen u aktivnu rezervu zaključuje tipski ugovor sa jedinicom ranga brigade ili višeg, o služenju u aktivnoj rezervi do dve godine. ${ }^{34}$ Ugovorom se određuju uslovi, vreme, način i poslovi na kojima bi se angažovalo lice u aktivnoj rezervi, prava i obaveze angažovanih lica za vreme izvršavanja konkretnih dužnosti u Vojsci Srbije i stručnih poslova u Ministarstvu odbrane i način njihovog finansiranja.

U slučaju utvrđenih potreba za angažovanjem na školovanju za specijalnost roda ili službe u kojoj je raspoređen, pohađanje kurseva, seminara i studijskih programa, obučavanja radi sticanja sertifikata o osposobljenosti za učešće u određenoj multinacionalnoj operaciji, upućivanja u određenu multinacionalnu operaciju i vršenja vojne službe za određeno vreme, sa aktivnim rezervistom se zaključuje pojedinačni ugovor, a u skladu sa uslovima utvrđenim propisima o VS.

$\mathrm{Na}$ osnovu svega iznetog, nadležni organ može pozvati pripadnika aktivne rezerve za vreme trajanja ugovora, po planu i na zahtev starešine ranga komandanta brigade u čijem je sastavu rezervista nalazi, zbog:

1) Izvođenja redovne ili intenzivne obuke do 45 dana, a na osnovu usvojenog godišnjeg plana obuke lica u rezervnom sastavu,

2) Stipendiranja, odnosno upućivanja na školovanje ili druge oblike stručnog usavršavanja u okviru specijalnosti, na osnovu utvrđene potrebe za školovanjem ili usavršavanjem lica iz svog sastava,

3) Izvođenja obuke do 3 meseca (90 dana) radi sticanja sertifikata o osposobljenosti za potrebe upućivanja u odobrene multinacionalne operacije prema usvojenom godišnjem planu i odlukama nadležnih organa,

4) Angažovanja do 6 meseci (180 dana) u odobrenoj multinacionalnoj operaciji za koju je osposobljen, u skladu sa odlukama nadležnih organa kojima je određen broj i struktura lica u aktivnoj rezervi koja se mogu upućivati u multinacionalne operacije van granica Republike Srbije i

\footnotetext{
${ }^{32}$ Vidi Uredbu o službi u aktivnoj rezervi ("Službeni glasnik RS" broj 47/11), član 2.

${ }^{33}$ Zakon o vojnoj, radnoj i materijalnoj obavezi ("Službeni glasnik RS" broj 88/09), član 55.

${ }^{34}$ Isto, član 56.
} 
5) Neposrednog prijema u vojnu službu zaključivanjem ugovora o vršenju konkretne vojne dužnosti, odnosno stručnog posla na određeno vreme, radi popune formacijskih mesta ili vršenja privremenih ili povremenih poslova.

Stručni poslovi odnosno vojne dužnosti na kojima se pripadnik aktivne rezerve može angažovati su svi stručni poslovi i vojne dužnosti iz komandi, jedinica i ustanova Vojske Srbije, za koje ispunjava propisane uslove na osnovu utvrđene potrebe službe:

1) za angažovanje u jedinici Vojske Srbije radi pružanja pomoći civilnim organima ili u slučaju vanrednog stanja proglašenog odlukom nadležnog organa,

2) za angažovanje na privremenim ili povremenim poslovima usled povećanja obima poslova ili radi produženja započetih radova čije bi obustavljanje ili prekidanje imalo štetne posledice za operativnu sposobnost komande, jedinice ili ustanove Vojske Srbije,

3) za angažovanje za izvršavanje obaveza preuzetih zaključenim međunarodnim ugovorima u oblasti odbrane i vojne saradnje koji se ne mogu izvršiti angažovanjem stalnog profesionalnog sastava Vojske Srbije,

4) za popunu slobodnih ili upražnjenih formacijskih mesta usled organizacijskih promena u Vojsci Srbije, kada se popuna ne može obezbediti redovnim prijemom, premeštajem ili na drugi propisani način i

5) radi zamene odsutnog pripadnika Vojske Srbije ili lica koje traje duže od šest meseci.

Licima koja sklope ugovor u svojstvu pripadnika aktivne rezerve određuje se i ratni raspored u komandama, jedinicama i ustanovama Vojske Srbije i Ministarstva odbrane, sa kojima su sklopili ugovor o angažovanju. Na taj način se obezbeđuje da se tim licima, eventualno, ne odredi ratni raspored u nekoj drugoj jedinici - ustanovi Vojske Srbije.

Građanin Republike Srbije postaje vojni obveznik, odnosno lice u rezervnom sastavu u svojstvu pripadnika pasivne rezerve, činom određivanja ratnog rasporeda u komandama, jedinicama i ustanovama Vojske Srbije i Ministarstva odbrane. ${ }^{35}$

Pripadnici pasivne rezerve se raspoređuju načelno po teritorijalnom principu. Pasivna rezerva popunjava se i profesionalnim oficirima, podoficirima i vojnicima kojima je prestala profesionalna vojna služba, a ispunjavaju propisane kriterijume.

Raspoređivanje na dužnosti u ratnim komandama, jedinicama i ustanovama Vojske Srbije vrši se prema vojnoevidencionim specijalnostima, a u vojnim jedinicama i ustanovama Ministarstva odbrane i prema sposobnosti za vršenje službe. Imajući u vidu da su vojne ustanove neposredno potčinjene Ministarstvu odbrane - usko specijalizovane, neborbene (zdravstvene, obrazovne, naučne, izdavačke, usko strukovno-zanatske i sl.), onda je njihova popuna moguća i pripadnicima rezervnog sastava koji su osposobljeni u građanstvu završetkom odgovarajućeg vida školovanja ili usavršavanja.

Raspoređivanje pripadnika pasivne rezerve vrši se po propisanom redu prvenstva i kriterijumima: $^{36}$

1) u ratne komande, jedinice i ustanove Vojske Srbije,

2) u vojne jedinice i vojne ustanove Ministarstva odbrane,

3) u Ministarstvo unutrašnjih poslova,

4) u jedinice i organe civilne zaštite,

\footnotetext{
${ }^{35}$ Zakon o vojnoj, radnoj i materijalnoj obavezi ("Službeni glasnik RS" broj 88/09 ), član 54.

${ }^{36}$ Uredba o kriterijumima za raspoređivanje građana i materijalnih sredstava za potrebe odbrane i popune Vojske Srbije (Odluka Vlade RS 05 broj 110-7295/2010 od 14.10.2010), član 7.
} 
5) u organe, jedinice i službe osmatranja, obaveštavanja i uzbunjivanja i

6) u državne organe, privredna društva, druga pravna lica i kod preduzetnika koji proizvode predmete, odnosno vrše usluge od posebnog značaja za odbranu zemlje.

\section{Popuna komandi, jedinica i ustanova aktivnom i pasivnom rezervom}

Komande, jedinice i ustanove Vojske Srbije mogu biti stalne i privremene strukture, a po nameni organizovane u: snage za reagovanje, glavne odbrambene snage i snage ojačanja. ${ }^{37}$

Snage za reagovanje čine moderno opremljene, osposobljene i popunjene jedinice visokog stepena razvijenosti. Osnovna su snaga VS za reagovanje na pretnje bezbednosti i dele se na: snage za hitno reagovanje i snage za brzo reagovanje.

Snage za hitno reagovanje čine profesionalne jedinice visokog stepena razvijenosti. Namenjene su za kontrolu i zaštitu vazdušnog prostora, protiv teroristička, protiv pobunjenička, diverzantska i protiv diverzantska dejstva i službu traganja i spasavanja.

Snage za brzo reagovanje čine profesionalne jedinice visokog stepena razvijenosti, osposobljene za: odbranu zemlje od oružanog ugrožavanja, stvaranje uslova za mobilizaciju i narastanje glavnih odbrambenih snaga i snaga ojačanja, kao i učešće u multinacionalnim operacijama i međunarodnoj vojnoj saradnji.

Glavne odbrambene snage čine deo Vojske Srbije opremljen i osposobljen za odbranu od oružanog ugrožavanja spolja, protiv pobunjenička dejstva i podršku civilnim vlastima, koje se sastoje od mirnodopskih komandi i jedinica Vojske Srbije i imaju niži stepen razvijenosti od snaga za reagovanje.

Snage ojačanja čine deo Vojske Srbije opremljen i osposobljen za izvršavanje zadataka odbrane teritorije u dodeljenim zonama odgovornosti i popunjavaju se iz rezerve. Zadaci tih snaga su odbrana pravaca i objekata u zoni odgovornosti i podrška civilnim vlastima i stanovništvu u situacijama kada su ugroženi ljudski životi, životna sredina i materijalna dobra.

Struktura snaga VS sa vremenom gotovosti za upotrebu i raspoloživošću snaga prikazana je na grafikonu.

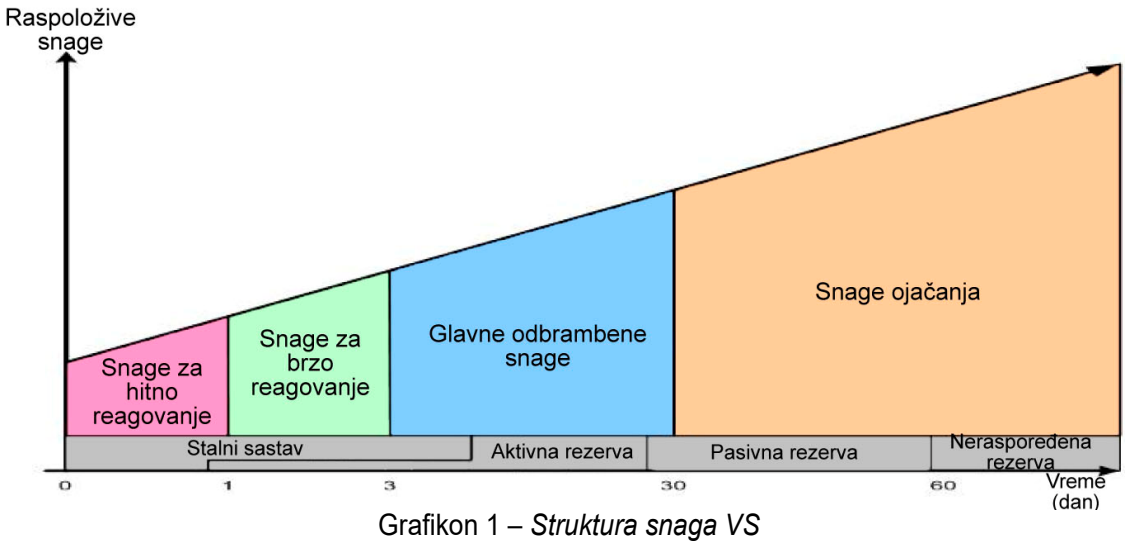

${ }^{37}$ Doktrina Vojske Srbije, Beograd, 2010, strana 20. 
Klasifikacija po stepenu razvijenosti određuje se za jedinice četa - baterija i bataljondivizion-eskadrila-odred. ${ }^{38}$ Nivo gotovosti, a samim tim i stepen razvijenosti kreće se od R-0 do R-4. Oni definišu i potrebno vreme gotovosti jedinica za upotrebu, ali i ostale važne elemente, što možemo videti u tabeli 1 . Posebno pitanje je stepen naprezanja ovih snaga (drugim rečima u uslovima najvećeg naprezanja, koliko možemo angažovati ovih snaga, a u isto vreme imati i projektovanu rezervu za rotaciju ili smenu) i to nije deo ovog teksta, ali je svakako veoma važno državno pitanje u celini.

Tabela 1 - Pregled nivoa gotovosti i stepena razvijenosti jedinica VS

\begin{tabular}{|l|l|c|c|c|c|}
\hline \multicolumn{2}{|c|}{ Nivo gotovosti } & $\begin{array}{c}\text { Stepen } \\
\text { razvijenosti u \% }\end{array}$ & $\begin{array}{c}\text { Vreme } \\
\text { gotovosti za } \\
\text { upotrebu }\end{array}$ & $\begin{array}{c}\text { Popunjenost } \\
\text { opremom u \% }\end{array}$ & Napomena \\
\hline Trenutna & R-0 & preko 90 & do 24 časa & 100 & \\
\hline Visoka & R-1 & 70 do 90 & do 72 časova & 100 & \\
\hline Srednja & R-2 & 30 do 70 & do 15 dana & 100 & \\
\hline Niska & R-3 & 10 do 30 & do 30 dana & 80 & \\
\hline Vrlo niska & R-4 & do 10 & do 60 dana & 60 & \\
\hline
\end{tabular}

$\mathrm{Na}$ osnovu doktrinarnih rešenja, nivoa gotovosti i stepena razvijenosti jedinica VS, može se zaključiti da snage za reagovanje čine jedinice VS popunjene profesionalnim vojnim licima, sa trenutnim (R-0) i visokim (R-1) stepenom razvijenosti, da glavne odbrambene snage čine jedinice sa srednjim i niskim stepenom razvijenosti (R-2 i R-3) i da snage ojačanja čine jedinice sa vrlo niskim stepenom razvijenosti (R-4).

Doktrinarna rešenja, u vezi snaga za reagovanje, koje čine profesionalne jedinice, navodi nas na zaključak da će pripadnici aktivne rezerve težišno popunjavati jedinice sa srednjim nivoom gotovosti (R-2) i razvijenosti od 30-70\%, odnosno glavne odbrambene snage.

Sa aspekta sprovođenja koncepta aktivne rezerve u popuni jedinica mirnodopskog sastava Vojske Srbije, značajno je popunjavanje snaga za reagovanje aktivnom rezervom.

I pored doktrinarnog stava o profesionalnosti u popuni, realno je angažovanje aktivne rezerve u sastavu snaga za brzo reagovanje, radi popune upražnjenih formacijskih mesta za određeni vremenski period (recimo za vreme angažovanja dela pripadnika ovih jedinica u multinacionalnim operacijama u regionu i svetu, raskida ugovora većeg broja profesionalnih pripadnika ili do završetka usavršavanja, specijalizacije i slično).

Upoređivanjem odredbi Zakona o upotrebi Vojske Srbije i drugih snaga odbrane u multinacionalnim operacijama van granica Republike Srbije kojim se aktivnoj rezervi daje mogućnost za učešće u operacijama očuvanja, održavanja i izgradnje mira u svetu i namene snaga za brzo reagovanje, u delu koji se odnosi na učešće u multinacionalnim operacijama, zaključujemo da se aktivna rezerva u toj misiji može upotrebiti u sastavu već napomenutih snaga, bez obzira na princip profesionalnosti.

${ }^{38}$ Pravilnik za unutrašnje uređenje i sistematizaciju formacijskih mesta u Vojsci Srbije (SVL broj 27/09 i 31/10), član 29. 
Doktrinarno određenje profesionalnosti snaga za reagovanje trebalo bi shvatiti kao opšte načelo-princip, a ne kao striktnu primenu u praksi, imajući u vidu mesto i ulogu aktivne rezerve u misijama i zadacima Vojske Srbije. Polazeći od cilja uvođenja aktivne rezerve, a to je obezbeđenje dodatnih ljudskih resursa, koji će omogućiti pouzdanu i efikasniju popunu jedinica motivisanim i obučenim kadrom, kao i da komande, jedinice i ustanove Vojske Srbije izvršavaju misije i zadatke i u miru, popuna snaga za brzo reagovanje, odnosno jedinica sa trenutnim (R-0) i visokim (R-1) stepenom razvijenosti je moguća i opravdana. Već navedenom ide na ruku i mogućnost godišnjeg obučavanja aktivne rezerve do 45 dana, kao i motivisanost ovog ljudstva s obzirom na princip dobrovoljnosti.

I pored svega ovoga Koncept aktivne rezerve i pored pozitivnog zakonskog određenja i predviđanja u dokumentima planiranja razvoja (strategijskim pregledom odbrane predviđeno je 2.000 lica za popunu mirnodopske vojske aktivnom rezervom) nije zaživeo u komandama, jedinicama i ustanovama VS.

U toku 2014. godine, preduzeti su određeni koraci koji bi mogli dovesti do implementacije ovog koncepta u jedinicama VS. Institut za strategijska istraživanja u saradnji sa Upravom za ljudske resurse (J-1) Generalštaba VS, sproveo je empirijsko istraživanje, putem anketiranja dela vojnika na dobrovoljnom služenju vojnog roka, vojnika u pasivnoj rezervi, profesionalnih vojnika i građana preko sajta Ministarstva odbrane o zainteresovanosti za službu u aktivnoj rezervi. Na osnovu rezultata istraživanja koji su bili povoljni, odlučeno je da se „pilot“ programom u drugoj polovini 2015. godine primi određeni broj lica u aktivnu rezervu u jedinice Kopnene vojske.

Što se tiče implementacije taj koncept još u povoju, da će u narednom periodu njegovo oživljavanje pre svega zavisiti od finansijskih izdvajanja države, ali da može u budućnosti činiti značajan kontigent lica, koji uz predviđeno osposobljavanje i angažovanje, može unaprediti operativne i funkcionalne sposobnosti Vojske Srbije.

Da bi odredili snage koje bi se mogle popuniti pasivnom rezervom, treba uporediti odredbe Zakona o vojnoj, radnoj i materijalnoj obavezi, Doktrinu Vojske Srbije (u delu koji se odnosi na funkcionalnu organizaciju Vojske Srbije) i Pravilnik za unutrašnje uređenje i sistematizaciju formacijskih mesta u Vojsci Srbije ${ }^{39}$ (u delu koji se odnosi na klasifikaciju jedinica po stepenu razvijenosti).

Imajući u vidu izneta upoređivanja, može se doći do zaključka da će se pasivnom rezervom popunjavati komande, jedinice i ustanove, koje čine glavne odbrambene snage i snage ojačanja. ${ }^{40}$

Pasivnom rezervom popunjavaće se deo glavnih odbrambenih snaga i to one koje se odnose na komande, jedinice i ustanove Kopnene vojske, Ratnog vazduhoplovstva i protiv vazduhoplovne odbrane i dela prištapskih jedinica GŠ VS, sa srednjim i niskim stepenom razvijenosti (R-2 i R-3), do ratne formacije.

Doktrinarna opredeljenja da snage ojačanja izvršavaju „zadatke odbrane teritorije u dodeljenim zonama odgovornosti i popunjavaju se iz rezerve" ${ }^{\text {"41 }}$, navode nas na zaključak da će, veći deo ove rezerve popunjavati upravo teritorijalne brigade Vojske Srbije.

\footnotetext{
${ }^{39}$ Pravilnik za unutrašnje uređenje i sistematizaciju formacijskih mesta u Vojsci Srbije (SVL 27/09 i 31/10), član 29.

40 "glavne odbrambene snage ... mirnodopskih komandi i jedinica Vojske Srbije i imaju niži stepen razvijenosti od snaga za reagovanje." i "snage ojačanja ...popunjavaju se iz rezerve." (Doktrina Vojske Srbije, Beograd, 2010, strana 20).
} 
Stoga, treba identifikovati izazove, sa kojim se mogu suočiti jedinice Vojske Srbije u popuni aktivnom i pasivnom rezervom.

$\mathrm{U}$ tom smislu, pitanje koje se nameće i predstavlja svojevrsni izazov u popuni ratnih jedinica pasivnom rezervom u današnje vreme je mogućnost korišćenja prava rezervista na prigovor savesti. ${ }^{42}$

Kada bi matematički proračunavali koliko pripadnika, teoretski može iskoristiti ovo pravo, sigurno bi došli do podatka, da je to preko preko $90 \%$ od ukupnog broja lica raspoređenih u pasivnoj rezervi. Pravo na prigovor savesti ne bi mogli ostvariti, samo rezervisti koji su u poslednje četiri godine odslužili vojni rok, što je oko pet do sedam hiljada pripadnika, s obzirom na zainteresovanost regruta za dobrovoljnim služenjem vojnog roka (četiri partije godišnje, a u partiji oko 300 do 400 dobrovoljaca).

Opet, ako teoretski posmatramo, postoji mogućnost da bi jedan deo pripadnika pasivne rezerve, ovo pravo iskoristio baš u momentu kada bi trebao biti upućen u ratnu jedinicu na izvršenje borbenog zadatka. Problem se usložava, čitavim nizom „abolicija“43 građana, koji su lični interes stavili iznad kolektivnog, koji su prekršili zakon o vojnoj obavezi i koji se nisu odazvali pozivu države da je brane u periodu od 1991. do 1999. godine. Zbog toga sistem odbrane i država u celini, trebaju pronaći zakonski okvir i model delovanja, kako bi se obezbedila nesmetana popuna ratnih jedinica i u ovakvim situacijama.

Zakonski okvir, je predvideo mogućnost da u vanrednom i ratnom stanju Narodna skupština može odobriti odstupanje od Ustavom garantovanih ljudskih i manjinskih prava. ${ }^{44}$

Pored definisanja u Zakonu o odbrani, ove mere su ušle i u sam Ustav Republike Srbije. ${ }^{45}$ Drukčije rečeno, ovakva odluka će možda biti neizbežna, jer proglašenjem vanrednog ili ratnog stanja, time bi se izbeglo narušavanja operativnih sposobnosti ratnih jedinica, kao i i sama odbrana zemlje.

Veliki izazov u popuni pasivnom rezervom takođe može predstavljati i zainteresovanost za dobrovoljno služenje vojnog roka koja ako pokaže tendenciju pada, tada se možda neće moći obezbediti potrebna brojna veličina rezervnog sastava i adekvatnih specijalnosti vojnika u pasivnoj rezervi, što bi za posledicu imalo postepeno smanjivanja broja osposobljenih vojnih obveznika za raspored u ratne jedinice, a naročito obveznika do 35 godina života.

Identifikovanje i sagledavanje ovih najvažnijih izazova u popuni ratnih jedinica navodi na razmišljanje o „odmrzavanju“ obaveze služenja vojnog roka, kako bi svi građani Srbije bili ravnopravni u pravima i dužnostima odbrane Republike Srbije, a popuna stabilna i predvidiva.

\footnotetext{
${ }^{41}$ Isto.

${ }^{42}$ Vidi Zakon o civilnoj službi ("Službeni glasnik RS" broj 88/09), član 3.

${ }^{43}$ Dosad su doneta tri zakona o amnestiji kada je reč o neispunjenju vojne obaveze. Prvim zakonom 1996. god. amnestirani su građani koji su do 14. decembra 1995. god. izbegavali služenje vojnog roka, da bi se zatim amnestija Zakonom iz 2001. god. dala osobama koji do 7. oktobra 2000. god. nisu ispunili vojnu obavezu. Poslednjim zakonom iz 2006. god. obuhvaćene su osobe koje nisu ispunile obavezu od 7. oktobra 2000. do 18. aprila 2006. god.

${ }^{44}$ Vidi Zakon o odbrani ("Službeni glasnik RS" broj 116/07, 88/09 i 10/15), član 91.

${ }^{45}$ Samo u dva Ustavom utvrđena slučaja data je mogućnost da se propišu mere odstupanja od Ustavom zagarantovanih ljudskih prava. Odstupanje je moguće uvesti samo u slučaju proglašenja vanrednog ili ratnog stanja.
} 


\section{Zaključak}

S ciljem uspostavljanja efikasnog i ekonomski održivog sistema odbrane Republike Srbije u kontinuiranom procesu reforme sistema odbrane, koji se sprovodi na osnovu utvrđene politike odbrane, a radi usklađivanja sistema odbrane sa izazovima, rizicima i pretnjama bezbednosti, prihvaćen je i normativno-pravno uređen sistem popune Vojske Srbije rezervnim sastavom.

Primenom koncepta aktivne i pasivne rezerve obezbeđuje se neophodan ljudski potencijal za popunu Vojske Srbije radi izvršavanja dodeljenih misija i zadataka.

Uvođenje aktivne, odnosno rezerve sa zaključenim ugovorom, potreba je Vojske Srbije za malobrojnom, ali dobro obučenom rezervom, koja će omogućiti pouzdanu popunu dela formacijskih mesta mirnodopskih jedinica na zadacima održavanja operativnih i funkcionalnih sposobnosti i angažovanja u misijama.

Zakonsko, pravno i doktrinarno uređenje angažovanja aktivne i pasivne rezerve u misijama i zadacima Vojske Srbije, regulisano je Zakonom o Vojsci Srbije, Zakonom o vojnoj, radnoj i materijalnoj obavezi, Doktrinom Vojske Srbije, Uredbom o službi u aktivnoj rezervi i drugim podzakonskim aktima.

Doneta zakonska i doktrinarna rešenja pružaju okvir za implementaciju koncepta aktivne i pasivne rezerve u izvršavanju misija i zadataka Vojske Srbije.

Upoređivanjem doktrinarnih rešenja i zakonske regulative, identifikovali smo da bi aktivnom rezervom popunjavali glavne odbrambene snage i to jedinice sa srednjim nivoom gotovosti i razvijenosti (R-2), dok bi pasivnom rezervom popunjavali glavne odbrambene snage u delu jedinica Kopnene vojske, Ratnog vazduhoplovstva i protiv vazduhoplovne odbrane i prištapskih jedinica Generalštaba, do ratne formacije i težišno snage ojačanja, odnosno teritorijalne snage vrlo niske gotovosti i razvijenosti (R-4).

Zakonom o upotrebi Vojske Srbije i drugih snaga odbrane u multinacionalnim operacijama van granica Republike Srbije, predviđeno je da u multinacionalne operacije mogu biti upućeni pripadnici aktivne rezerve. S obzirom na to da su snage za brzo reagovanje namenjene za učešće u multinacionalnim operacijama, to znači da se aktivna rezerva u toj operaciji angažuje u snagama za brzo reagovanje, bez obzira na princip profesionalnosti tih snaga. Primenjujući takav metod angažovanja, dolazimo do logičnog zaključka da se pripadnici aktivne rezerve mogu upotrebiti i u drugim misijama Vojske Srbije u sastavu snaga za brzo reagovanje. S druge strane, nije opravdano aktivnom rezervom popunjavati jedinice sa niskim (R-3) i vrlo niskim (R-4) stepenom razvijenosti, jer angažovanjem aktivne rezerve u ovakvim jedinicama nećemo poboljšati njene ukupne sposobnosti, s obzirom na popunjenost i razvijenost do $10 \% \mathrm{i}$ od $10 \%$ do $30 \%$.

$\mathrm{Na}$ osnovu svega iznetog može se dati okvir angažovanja aktivne i pasivne rezerve u misijama i zadacima Vojske Srbije:

Aktivna i pasivna rezerva, može se angažovati u izvršavanju zadataka odbrane Republike Srbije od oružanog ugrožavanja spolja:

- kao snage za odvraćanje od oružanog ugrožavanja (samo aktivna rezerva),

- kao snage za odbranu teritorije i

- kao snage za odbranu vazdušnog prostora. 
Aktivna rezerva, može se angažovati u izvršavanju zadataka učešća u izgradnji i očuvanju mira u regionu i svetu:

- kao snage za učešće u multinacionalnim operacijama.

Aktivna i pasivna rezerva, može se angažovati u izvršavanju zadataka podrške civilnim vlastima u suprotstavljanju pretnjama bezbednosti:

- kao snage za pomoć civilnim vlastima u suprotstavljanju unutrašnjem ugrožavanju bezbednosti, terorizmu, separatizmu i organizovanom kriminalu (samo aktivna rezerva) i

- kao snage za pomoć civilnim vlastima u slučaju prirodnih nepogoda, tehničko-tehnoloških i drugih nesreća.

U bližoj budućnosti realno je postepeno i sistematično smanjivanja brojnog stanja ratne vojske u smislu smanjenja angažovanja lica iz pasivne rezerve na račun osposobljenosti, opremljenosti i operativnih sposobnosti profesionalnog sastava i brojnosti i sposobnosti pripadnika aktivne rezerve. Na taj način racionalizovao bi se odnos profesionalnog sastava, aktivne i pasivne rezerve, ali pri tome bi se moralo voditi računa, da se ni na koji način ne ugrozi operativna sposobnost Vojske Srbije (ili da kažemo najveće moguće naprezanje snaga, koje bi dovelo do situacije kao i 1999. godine i mogućnosti napada sa svih strana).

Radi realizacije sigurne i efikasne popune rezervnim sastavom Vojske Srbije potrebno je sigurno obezbediti dodatna novčana sredstva radi opremanja savremenim naoružanjem i vojnom opremom i brojnijem učešću aktivne u odnosu na pasivnu rezervu.

\section{Literatura}

[1] Vujaklija M.: Leksikon stranih reči i izraza, Beograd, Prosveta, 1980.

[2] Vojni leksikon, Beograd, Vojno izdavački zavod, 1981.

[3] Vojna enciklopedija, tom 8, Beograd, Redakcija vojne enciklopedije, 1996.

[4] Doktrina Vojske Srbije, Beograd, 2010.

[5] Karanović N.: Vojna, radna i materijalna obaveza, prigovor savesti i civilna služba u budućim zakonskim rešenjima. Vojno delo, br. 4/2008.

[6] Zakon o odbrani, Službeni glasnik RS, br. 116/07, 88/2009 i 10/15.

[7] Zakon o Vojsci Srbije, Službeni glasnik RS, br. 116/07, 88/09 i 10/15.

[8] Zakon o vojnoj, radnoj i materijalnoj obavezi, Službeni glasnik RS, br. 88/09.

[9] Zakon o upotrebi Vojske Srbije i drugih snaga odbrane u multinacionalnim operacijama van granica Republike Srbije, Službeni glasnik RS, br. 88/09.

[10] Zakon o civilnoj službi, Službeni glasnik RS, br. 88/09.

[11] Pravilnik za unutrašnje uređenje i sistematizaciju formacijskih mesta u Vojsci Srbije, Službeni vojni list, br. 27/09 i 31/10.

[12] Rečnik srpskog jezika, Novi Sad, Matica Srpska, 2007.

[13] Strategija nacionalne bezbednosti, Službeni glasnik RS, br. 88/09.

[14] Strategija odbrane Republike Srbije, Službeni glasnik RS, br. 88/09.

[15] Uredba o kriterijumima za raspoređivanje građana i materijalnih sredstava za potrebe odbrane i popune Vojske Srbije, Odluka Vlade RS br. 110-7295/2010 .

[16] Ustav Republike Srbije, 2006. 